\title{
Desmoid tumor of the neck: a case report
}

\author{
Tumor desmóide do pescoço: um relato de caso
}

Tumor desmoide del cuello: reporte de um caso

Luigi Ferreira e Silva ${ }^{1 *}$, Victor Luigi Oliveira de Franco², Ana Luiza Lopes de Freitas Freire ${ }^{1}$, Cecília Leite Gomes ${ }^{1}$, Karlla Lorenna dos Santos Anjos ${ }^{1}$, Vanessa Coutinho Aguiar Gomes ${ }^{1}$, Amanda Martins Umbelino ${ }^{1}$, Igor Isamu Couceiro Seto ${ }^{1}$, Diego Gadelha Vaz ${ }^{1}$, Isabela Bergh Pereira Macambira Martins ${ }^{3}$.

\begin{abstract}
Objective: To report a case of Desmoid Tumor in the cervical region. Case Report: A case of a large mass in the cervical region of a patient with progressive growth, neck pain and some move restriction, without other comorbidities. Imaging, histopathologic and immunohistochemical study were needed for diagnosis, surgical treatment and postoperative care. Imaging showed a $12.6 \times 5.7 \times 5.8 \mathrm{~cm}$ tumor, $\mathrm{T} 1$-weighted muscle isointense and T2-weighted hyperintense heterogeneous core, close to paravertebral muscles and pushing left sternocleidomastoid muscle laterally. The chosen treatment was complete tumor exeresis. Immunohistochemistry revealed myofibroblastic neoplasm compatible with desmoid fibromatosis with positivity for nuclear beta-catenin. Final Considerations: Large benign and infiltrative tumors need to be well conducted. It is essential that otolaryngologists are aware of the nature of these cases, differential diagnosis, treatment options and their possible complications, because eventually cases like this may appear requiring special care.
\end{abstract}

Keywords: Fibroma, Otolaryngology, Head and neck neoplasms, Beta-catenin.

\section{RESUMO}

Objetivo: Relatar um caso de Tumor Desmóide na região cervical. Detalhamento do Caso: Um caso de massa na região cervical de um paciente com crescimento progressivo, dor no pescoço e alguma com restrição de movimentação, sem outras comorbidades. Foram necessários estudos de imagem, histopatológicos e imuno-histoquímicos para diagnóstico, tratamento cirúrgico e cuidados pós-operatórios. A imagem mostrou um tumor de dimensões de 12,6 x 5,7 x 5,8cm, isointenso em T1 e um núcleo heterogêneo hiperintenso em T2, próximo aos músculos paravertebrais e empurrando lateralmente o músculo esternocleidomastóideo esquerdo. $O$ tratamento escolhido foi a exérese completa do tumor. A imunohistoquímica revelou neoplasia miofibroblástica compatível com fibromatose desmóide com positividade para beta catenina nuclear. Considerações Finais: Grandes tumores benignos e infiltrativos precisam ser bem conduzidos. É essencial que os otorrinolaringologistas estejam cientes da natureza desses casos, diagnóstico diferencial, opções de tratamento e suas possíveis complicações, já que eventualmente casos como este possam aparecer, sendo necessário um cuidado particular.

Palavras-chave: Fibroma, Otorrinolaringologia, Neoplasias de cabeça e pescoço, Beta catenina.

\footnotetext{
${ }^{1}$ Bettina Ferro de Souza University Hospital - Hospital Complex of UFPA (CHU-UFPA), Belém - PA

*E-mail: luigisilva1@gmail.com

2 University Center of Pará (CESUPA), Belém - PA.

3 João Barros Barreto University Hospital - Hospital Complex of UFPA (CHU-UFPA), Belém - PA.
} 


\section{RESUMEN}

Objetivo: Reportar um caso de tumor desmoide en la región cervical. Detalle del Caso: Un caso de una gran masa en la región cervical de un paciente con crecimiento progresivo, dolor de cuello y cierta restricción de movimiento, sin otras comorbilidades. Se necesitaron estudios de imagen, histopatológicos e inmunohistoquímicos para el diagnóstico, el tratamiento quirúrgico y la atención postoperatoria. Las imágenes mostraron un músculo isointenso T1 de $12.6 \times 5.7 \times 5.8 \mathrm{~cm}$ y un núcleo heterogéneo hiperintenso ponderado en T2, cerca de los músculos paravertebrales y el músculo lateral izquierdo del músculo esternocleidomastoideo pulsátil. El tratamiento elegido fue exéresis tumoral completa. La inmunhohistoquímica reveló neoplasia miofibroblástica compatible con fibromatosis desmoide con positividad para beta-catenina nuclear. Consideraciones Finales: Los tumores benignos e infiltrativos grandes deben realizarse bien. Es esencial que los otorrinolaringólogos conozcan la naturaleza de estos casos, el diagnóstico diferencial, las opciones de tratamiento y sus posibles complicaciones, ya que eventualmente pueden aparecer casos como este, que requieren atención especial.

Palabras clave: Fibroma, Otorrinolaringología, Neoplasias de cabeza y cuello, Beta catenina.

\section{INTRODUCTION}

Although $12 \%$ of the body is made up of soft tissue, only $1 \%$ of all tumors come from them (adipose tissue, smooth and skeletal muscle, cartilage, fibrous tissue, blood and lymphatic structures), with benign tumors being 100x more common than malignant ones. Fibroblastic tumors correspond to $76 \%$ of these tumors. However, only $27 \%$ of them affect head and neck region (RAZEK AA, et al., 2011).

Desmoid tumors (DT) - or deep fibromatosis - are abnormal growths tissues, which occur due to proliferation of fibroblasts from connective tissue and can occur anywhere in the body. They are usually considered benign, as they do not cause metastasis (spread to other tissues). However, DT can invade surrounding tissue, which make removal process more difficult. They can be intra-abdominal, when they arise from the tissue and ligaments that connects the abdominal organs, or extra-abdominal, when appearing in other regions of the body, such as shoulders, arms, legs and neck (NATIONAL LIBRARY OF MEDICINE, 2020).

The intra-abdominal DT mainly affects the female sex during pregnancy or in the immediate post childbirth period. The extra-abdominal DT occurs most commonly in the period of puberty until about 50 years, with no prevalence between genders. The shoulder musculature is the extra-abdominal site most frequently affected, followed by the chest and back and finally the musculature of the head and neck (GOTO T, et al., 2010). The frequency of DT in general is 2 to 4 cases per 1,000,000 individuals per year, with a small preponderance in women and a higher incidence in the $3^{\text {rd }}$ and $4^{\text {th }}$ life decades (SHINAGARE AB and HUANG BY, 2011).

Even though they are "benign", large tumors in the cervical region, it can cause several complications. Due to its size, the tumor may compress nearby structures, such as nerves and blood vessels, which can lead to pain and difficulty in venous return, respectively. Due to its location, it can cause difficulty in joints mobility, such as atlantoaxial joint. In addition, the tumor removal surgery itself also presents risks, such as damage to nerves that pass through the region (HARRÉUS U, et al., 2013).

Magnetic Nuclear Resonance (MRI) is the imaging gold-standard exam to characterize the tumor extension, as well as for following and monitoring. Image-guided biopsy is important to diagnosis confirmation (PENEL N, et al., 2017).

Surgical resection with tumor-free margins is the preconized treatment. As the tumor grows with projections into adjacent structures, it is not always possible to identify the tumor capsule, which impairs total resection with tumor-free margins. In these cases, the association with adjuvant radiotherapy is indicated to prevent local recurrence. For unresectable tumors or when the patient chose for non-surgical treatment, it can be considered as treatment options anti-hormonal drugs such as tamoxifen and chemotherapy. (ZUMÁRRAGA JP, et al., 2018). 
Studies suggest that clinical characteristics such as increased tumor size, young patient age and positive margin after surgical resection are associated with a greater possibility of tumor recurrence. Genetic mutations are also associated with a greater local recurrence, especially the S45F CTNNB1 mutation, which is suggested as a risk factor for recurrence after curative surgery (PENEL N, et al., 2017). Head and neck tumors are often considered challenging for surgical treatment due to proximity to vital structures. Besides that, there are morbidity associated with the procedure, difficult local control of the tumor and the possibility of spontaneous regression of the lesion (DIONISIOS AK, et al., 2018).

Eventually, cases of patients with cervical masses will be attended by otolaryngologists, due to these masses originate directly from organs such as larynx and neck muscle causing symptoms such as dysphonia or dysphagia (COHAN DM, et al., 2009). Thus, it is essential that otolaryngologists are aware of these cases, it's management and possible complications.

The objective of this study proposes to report a case of a 30-year-old female patient who took medical care complaining of a painful left neck mass, with progressive growth in 2 years and impaired neck mobility, opted for complete excision, with good response to surgical treatment.

\section{DETAILS OF THE CASE}

KCM, 30 years old, female, without comorbidities, comes to the Head and Neck Surgery service with a painfull cervical mass in the neck left, with moderately progressive growth for approximately 2 years, at the moment with restricted left head rotation and left lateral head tilt. No history of radiation exposure, traumas, previous treatments for any malignant disease or associated phenotypic, no behavioral or occupational risk factors and no family neoplastic history. No history of fever or weight loss. In continuous use of estrogen and progesterone-based contraceptives only.

On physical examination, a well adhered to deep layers hardened mass, painful on palpation and attempting to mobilization, without signs of inflammation. It's restricted lateral rotation movement and left inclination, without compromising left cingulate movement (Figure 1). There was no evidence of significant restrictions on movement of the left shoulder, however, during passive mobility, cervical pain irradiated to left forearm and arm. Otolaryngology examination, cardiopulmonary examination, abdominal examination, pelvic and genitourinary examination without changes.

Neck and cervical spine magnetic resonance imaging showed well defined expansive mass, laterally close to left paravertebral neck space and supraclavicular region, isointense to muscle in T1 weighted, heterogeneous, hyperintense and contrast enhancement nature in T2 weighted, measuring $12.6 \times 5.7 \times 5.8$ $\mathrm{cm}$, pushing left sternocleidomastoid muscle laterally, non-infiltrative, preserving adjacent structures (Figure 2A and 2B). Other cervical structures where preserved. Computed tomography of the chest, abdomen and pelvis did not reveal masses, nodules or anatomical asymmetries worthy of investigation.

A complete tumor removal surgery was performed, the intraoperative findings were little cleavage plan, adherence to soft muscle tissues and proximity to cervical vertebral spine, however with neurovascular structures preservation (Figure 3A and Figure 3B). There was moderate bleeding, but did not required blood transfusion. In postoperative care, the patient had mild cervical pain, no movements restrictions of left upper limb and cingulate, no dysphonia, acceptable blood-draining, being discharged in three days with prescription of symptomatic drugs. Antibiotic prophylaxis was used during anesthesia induction.

On outpatient return, the patient expressed satisfaction with the surgical result, remaining asymptomatic and without any loss of mobility of the neck and left upper limb or vocal changes, with surgical wound in good aspect of healing. Histopathological results described was fusocellular pattern neoplasm interspersed with poorly vascularized stroma and immunohistochemistry described myofibroblastic neoplasia with low malignant potential, compatible with desmoid fibromatosis with positivity for nuclear beta-catenin and very low proliferative index using KI-67 marker (Figure 4A and 4B).

In one-year follow-up, the patient remains asymptomatic in all aspects, without recurrences, no cervical tumor, no limitations in cervical and upper limb mobility. Cardiovascular, locomotor, genitourinary, neurological and respiratory systems with no changes, she chose to discontinue contraceptive medication. 
Figure 1 - Cervical inspection immediately before the procedure.

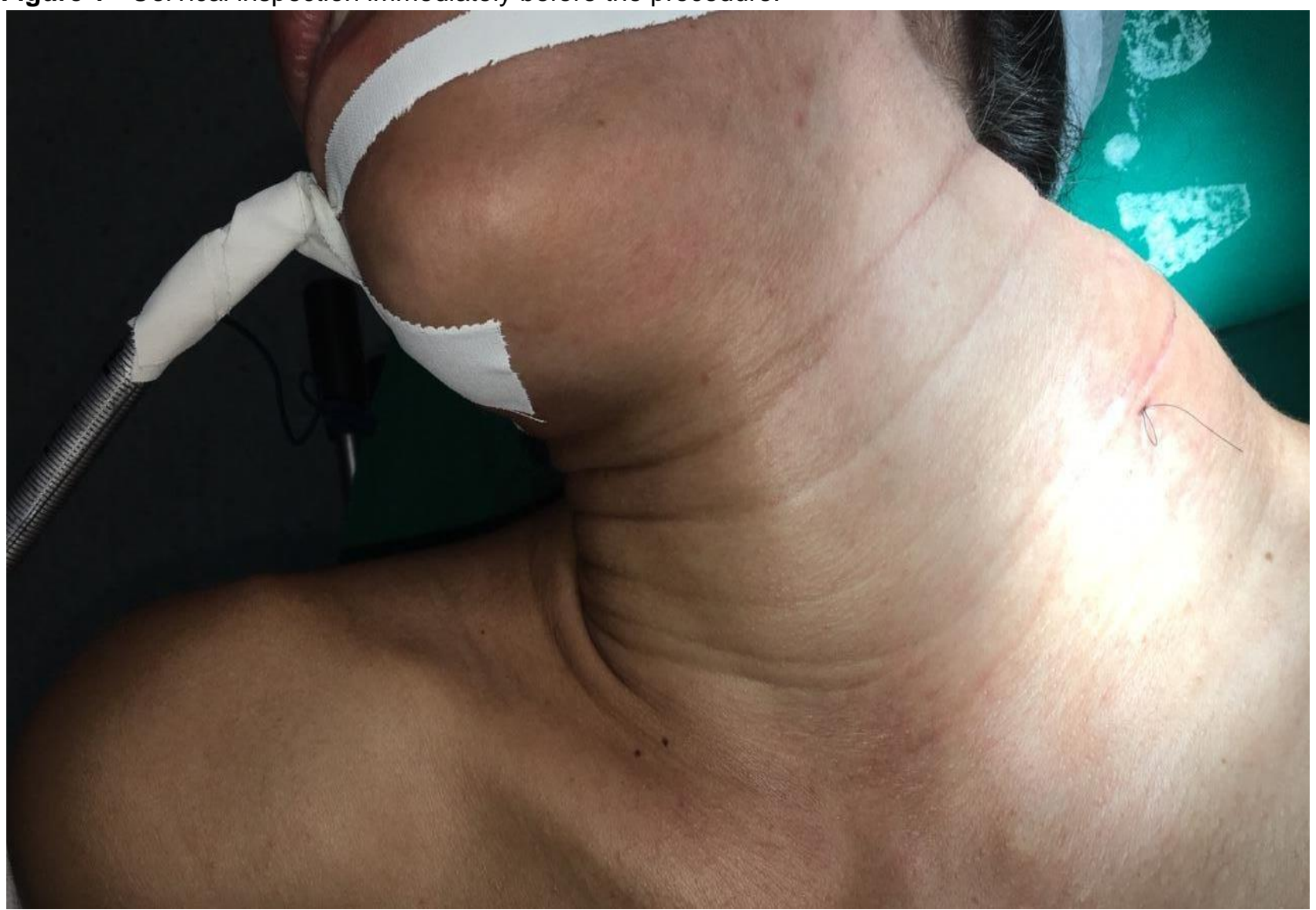

Source: Silva LF, et al., 2020.

Figure 2 - Magnetic resonance imaging showing a left large neck mass T1 weighted, muscle isointense (A). The same tumor, postcontrast T2 weighted, with heterogeneous core (B).

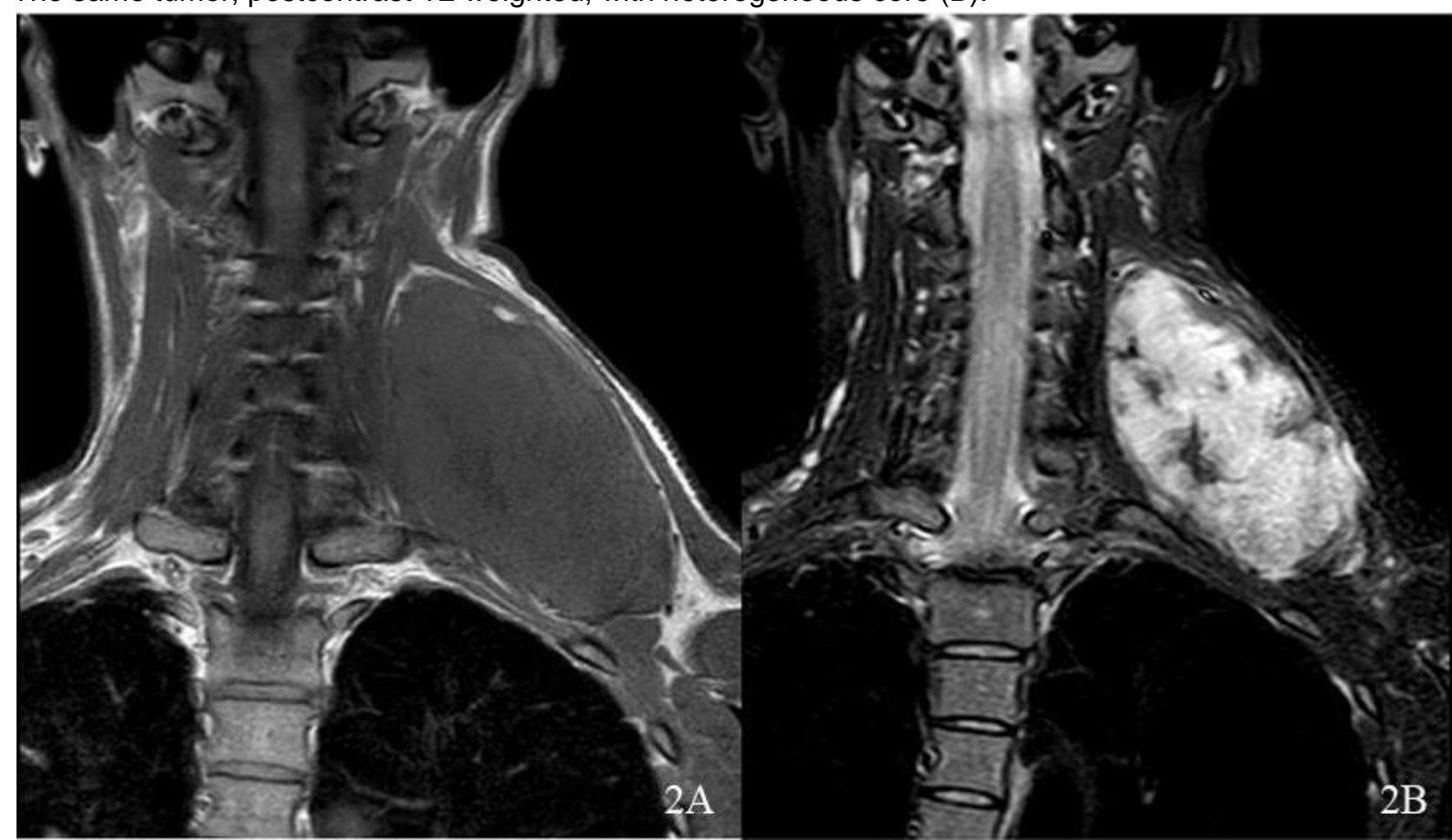

Source: Silva LF, et al., 2020. 
Figure 3 - Tumor exeresis by lateral cericotomy $(A)$. Surgical specimen completely removed, measuring approximately $12 \mathrm{~cm}(\mathrm{~B})$.

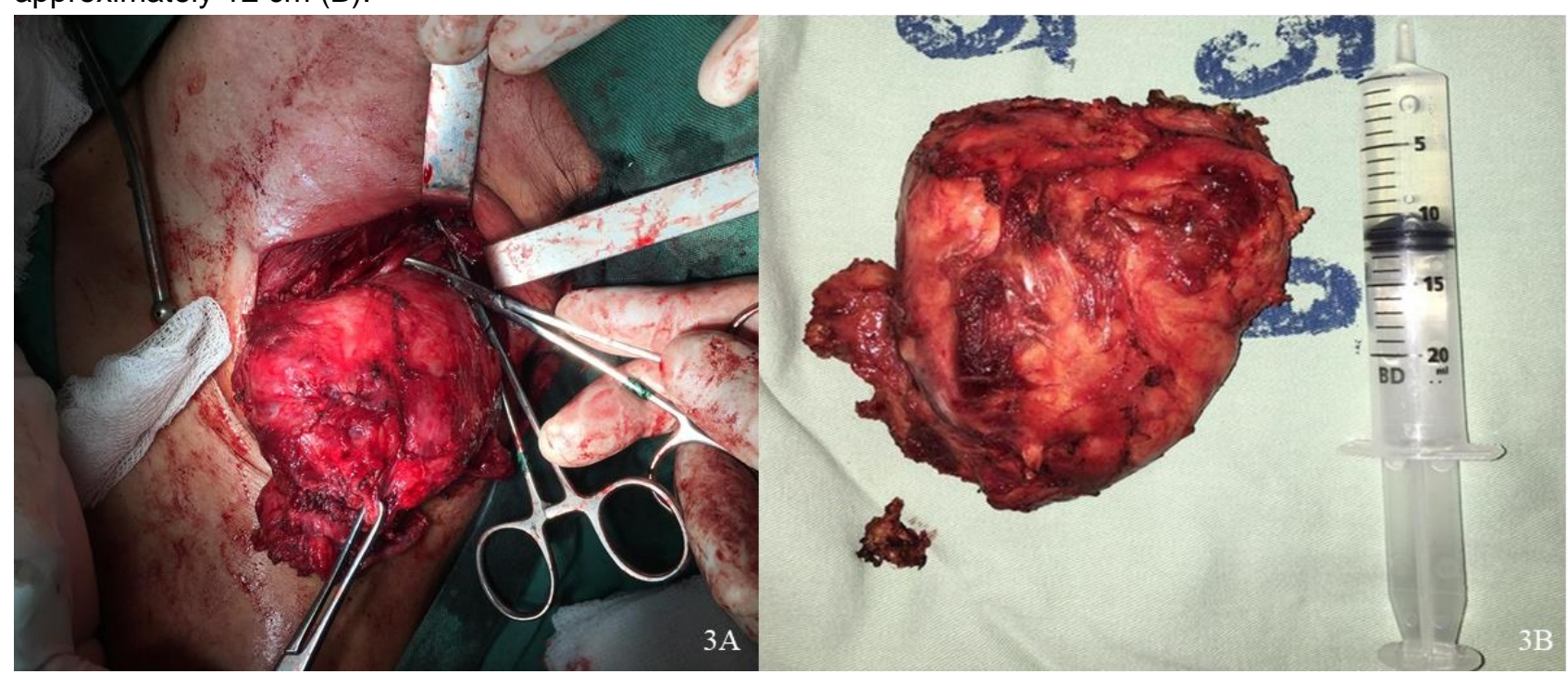

Source: Silva LF, et al., 2020.

Figure 4 - Histopatologic analysis showing fusocellular neoplasm and diffused fibroblast cells between dense stroma (Hematoxylin-Eosin, 400x) (A). Immunohistochemical analysis revealed nuclear beta-catenin positivity and very low proliferative index by KI-67 nuclear marker (Hematoxylin-Eosin 400x, Benchmark-GX-VentanaROCHE automatized immunohistochemical method) (B).

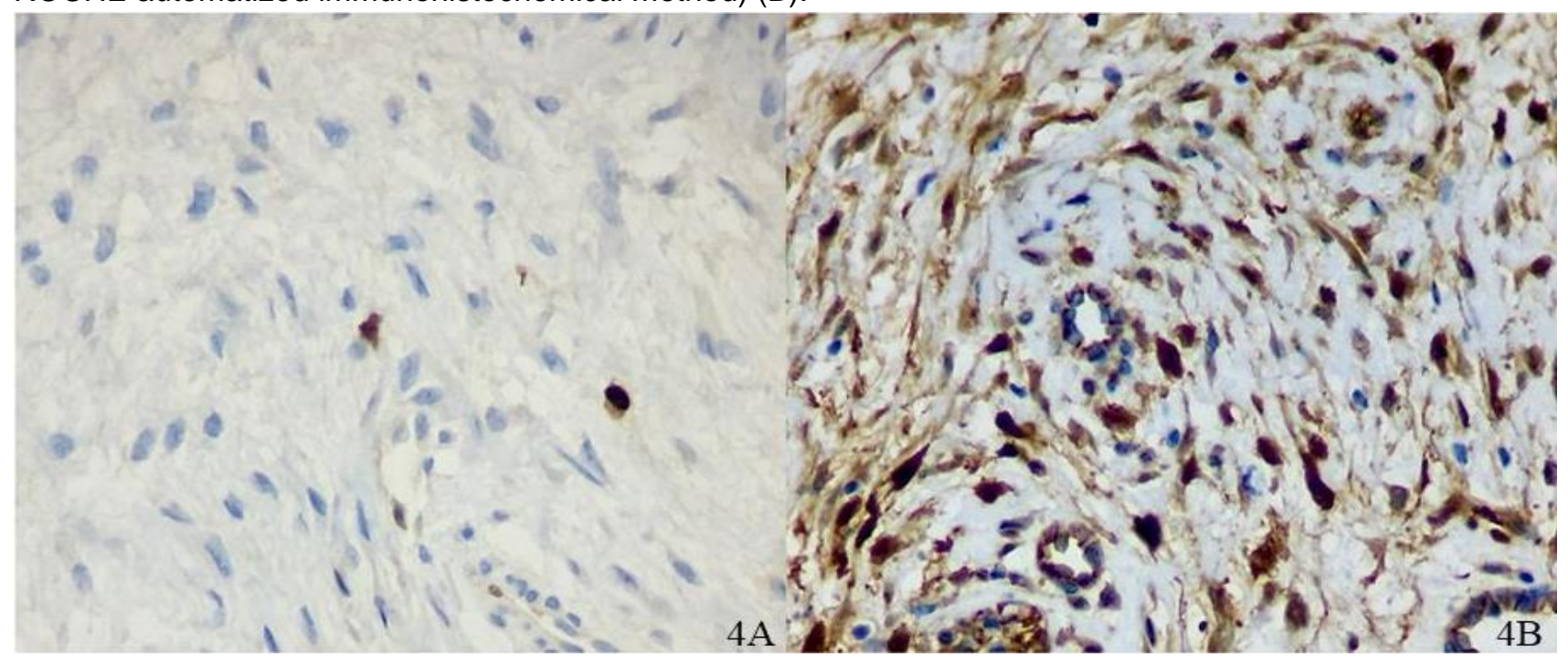

Source: Silva LF, et al., 2020.

\section{DISCUSSION}

Dermoid tumor is a benign fibrous neoplasm originated from any fibrous tissue in the body and it can grow in different locations (fascia, periosteum, muscle and aponeurotic structures). Differently from other benign tumors, its behavior commonly with infiltration and overgrowths of fibrous tissue, despite well-differentiated histology, usually sited in abdominal cavity. Approximately $1 / 3$ of the cases occurs in extra-abdominal DT sites - among 15\% in head and neck (PRABHU R, et al., 2013).

Its frequency corresponding to $0.03 \%$ of all neoplasms, only $7-15 \%$ are located in head and neck region. Affects young population, with a peak of incidence around 30 years, compatible with the case presented. The etiology is not yet fully clarified, a history of trauma or neck surgery are probable risk factors, however, there was no previous findings in this case report (BOUATAY R, et al., 2019). 
There is also a report of increased incidence after pregnancy or exposure to oral contraceptives, as well as spontaneous regression of the lesion during the climacteric period (MIYASHITA H, et al., 2016). This patient was using oral contraceptives for 10 years at the time of questioning.

The otolaryngologist is frequently the first health professional to provide medical care to these patients with neck masses, it is important that they know several differential diagnoses, allowing early access to proper treatment. Poor data are described in medical literature; however, head and neck variants of fibromatosis seem to be locally aggressive, turning it into fatal lesions with inoperable prognosis with bone and soft tissue invasion.

Pathogenesis includes abnormal responses of fibrotic formation, with immature fibroblastic origin with progressive activity, producing the neoplasm. Studies suggest a role in pathologic growth under reproductive system hormones (PRABHU R, et al., 2013). Histologic nature of the tumor shows mature fibroblasts with collagenous component forming interlaced trabeculae of fibrous tissue invading soft tissues such as muscle, fat and others, reaching nerves and vessels.

The invasion and mass effect are the main processes involved in symptomatic findings. When occurring with the shoulder, brachial plexus compression evidences numbness, paresthesia and weakness of the upper limb (PRABHU R, et al., 2013). In this case, neck's movement restriction occurred due to mass effect, preserving shoulder mobility, sensibility, and voice.

DT are usually more related to pain, grows in any regions of the body and it does not metastasize, but can be very infiltrative, making its removal more difficult (NATIONAL LIBRARY OF MEDICINE, 2020). In this case, a surgical resection with tumor-free margins was possible due to the non-infiltrative aspect of the tumor. DT is characterized by infiltrative growth and a tendency towards recurrence. To avoid local recurrence, an early diagnosis is required for this tumor type, which is difficult as most of these patients are asymptomatic (LING W, et al., 2013).

MRI is the most appropriate imaging method to better characterize the initial extension of DT and to monitor the surgical outcome. Imaging-guided core-needle biopsy is required to formally diagnose. The nuclear overexpression of beta-catenin is a useful diagnostic tool, but its sensitivity depends on the immunohistochemistry method used (PENEL N, et al., 2017).

Due to PKI-67, a nuclear protein, is associated with cell proliferation, being present in the phases of the cell mitotic cycle G1, S, G2 and mitosis, but completely absent in resting cells (phase G0). Thus, it's a marker for determining growth fraction of the cell population (BRUEY JM, et al., 2010). DT' origin is associated with mutations in either CTNNB1 gene or APC gene.

CTNNB1 being responsible for $85 \%$ of sporadic DTs and APC for the remaining $15 \%$. CTNNB1 is responsible for synthesizing the beta-catenin protein, while APC produces a protein capable to regulate betacatenin levels. Considering that beta-catenin assists in the expression of genes that promote cell proliferation and differentiation, its accumulation in cells promotes uncontrolled growth and division, either by mutations in CTNNB1 or APC genes (NATIONAL LIBRARY OF MEDICINE, 2020).

Uncertain etiology and the various locations makes its treatment extremely difficult. Optimal treatment remains controversial, and there is no definite and effective method of treatment (LING W, et al., 2013). However, complete resection or a wide surgical excision are the first choice therapy, although some authors affirmed that there were no significant difference between negative margins and microscopic positive margin regarding recurrence rate (HUANG K, et al., 2009).

Currently available data suggest that only a small percentage of DT are progressive and that most progressions are seen within 36 months' follow-up (BONVALOT S, et al., 2013). The 'wait and see' policy avoids inadequate treatment for DT that could spontaneously regress and discourages treatment for stable and poorly symptoms cases. Reasons for treatment (including surgery) are volumetric progression and symptom worsening. Radiotherapy is rarely used in DT tumor management. Adjuvant radiotherapy is proposed in cases of R1/R2 resection and in tumors located at critical sites (PENEL N, et al., 2017). 
Some researchers believe that radiotherapy does not reduce the postoperative local recurrence rate, and may lead to complications such as edema, cellulitis, fibrosis, ulcers, and pathological fractures. Radiotherapy even has the potential to induce other local malignant tumors, and should not be performed in patients with an initial negative margin but may be considered during postoperative follow-up. Postoperative supplemental radiotherapy is standard for patients with a positive margin, and can achieve an $80 \%$ local control rate (LIU X, et al., 2018).

Radiotherapy may be used for unresectable or recurrent DT as well as in patients who are at high risk for surgery. A recent metanalysis reported that combination of surgery and radiotherapy had a lower local failure rate compared to surgery alone. However, radiation therapy is also associated with significant morbidity and hence careful risk versus benefit analysis should be performed and therapeutic doses kept to as low as reasonably possible (GANESHAN D, et al., 2019).

Systemic therapy also plays an important part in the management, including anti-estrogenic drugs (tamoxifen and toremifene), non-steroidal anti-inflammatory drugs (meloxicam, indomethacin, sulindac and celecoxib), cytotoxic chemotherapy (doxorubicin, methotrexate and vinblastine) and tyrosine kinase inhibitors (imatinib, sunitinib, pazopanib, sorafenib, sirolimus). Those have been reported to be useful for achieving disease control in DT. Given the high toxicity profile of some of these agents, patients should be closely monitored for any potential treatment induced complications (GANESHAN D, et al., 2019).

Chemotherapy and endocrine targeted therapy are generally reserved for patients that cannot undergo surgery or radiotherapy because DT has invaded vital organs or the patient had multiple postoperative recurrences. For such patients, these treatments can reduce pain, symptoms and the tumor's size, creating opportunities for further surgery (LIU X, et al., 2018). For being a condition of well-differentiated fibroblasts and invasive behavior, recurrence is frequent, which occurs in 33\% of cases (TEIXEIRA LE, et al., 2016).

Due to the rare aspect pathology, there is no well-established management in medical literature, and surgical treatment or radiotherapy can be chosen, with no difference between treatments. However, the use of radiotherapy is still controversial, and in this case, surgery was encouraged to avoid further complications due to excessive radiation (XIAOSHUANG N, et al., 2019).

\section{FINAL CONSIDERATIONS}

The present report exposed a large and infiltrative neck mass in a young female patient with impaired neck and left upper limb mobility with previous use of oral contraceptive medication, submitted to lateral cervitocomy and complete tumor removal without complications. In postoperative period, there were no injuries or complications due to the surgery, evolving satisfactorily after one year follow-up. The authors emphasize the importance of large and infiltrative benign tumor well conducted by medical team. Despite its benign nature, a rapid growth and a high recurrence rate make this neoplasm a dramatic condition for patients and a challenge for medical management. Otolaryngologists and Head and Neck Surgeons should be aware of the clinical picture of neck masses associated with dysphonia or dysphagia, conducting the correct diagnosis and proper management of these cases and consequently improving the quality of life of patients.

\section{REFERENCE LIST}

1. BONVALOT $\mathrm{S}$, et al. Spontaneous regression of primary abdominal wall desmoid tumors: more common than previously thought. Annals of Surgical Oncology, 2013; 20: 4096-4102.

2. BOUATAY R, et al. Desmoid tumors of the head and neck: A case report. European Annals of Otorhinolaryngology Head and Neck Diseases, 2019; 136: 207-209.

3. BRUEY JM, et al. Circulating Ki-67 Protein in plasma as a Biomarker and Prognostic Indicator of Acute Lymphoblastic Leukemia. Leukemia Research, 2010; 34: 173-176.

4. COHAN DM, et al. Oropharyngeal cancer: Current Understanding and Management. Current Opinion in Otolaryngology \& Head and Neck Surgery, 2009; 17: 88-94. 
5. DIONISIOS AK, et al. Recurrent desmoid tumor of the neck: a case report of a benign disease with aggressive behavior. Case Reports in Otolaryngology, 2018; 2018: 6573587.

6. GANESHAN D, et al. Current Update on Desmoid Fibromatosis. Journal of Computer Assisted Tomography, 2019; 43: 29-38.

7. GOTO T, et al. Successful treatment of desmoid tumor of the chest wall with tranilast: a case report. Journal of Medical Case Reports, 2010; 4: 384.

8. HARRÉUS U, et al. Surgical errors and risks - The head and neck cancer patient. German Medical Science, 2013; 12: Doc 04.

9. HUANG K, et al. Prognostic factors for extra-abdominal and abdominal wall desmoids: a 20-year experience at a single institution. Journal of Surgical Oncology, 2009; 100: 563-569.

10. LING W, et al. Desmoid tumor of posterior cruciate ligament of the knee: a case report. BMC Musculoskeletal Disorders, 2013; 14: 69.

11. LIU X, et al. Misdiagnosis of aggressive fibromatosis of the abdominal wall: A case report and literature review. Medicine (Baltimore), 2018; 97: e9925.

12. MIYASHITA H, et al. Desmoid-type fibromatosis of the head and neck in children: a case report and review of the literature. Journal of Medical Case Reports, 2016; 10: 173

13. NATIONAL LIBRARY OFMEDICINE. 2020. In: Desmoid Tumor. Available from: https://ghr.nlm.nih.gov/condition/desmoid-tumor. Accessed March 22, 2020.

14. PENEL N, et al. Adult desmoid tumors: biology, management and ongoing trials. Current Opinion on Oncology, 2017; 29(4): 268-274.

15. PRABHU R, et al. Aggressive fibromatosis (desmoid tumour) of the head and neck: a benign neoplasm with high recurrence. BMJ Case Reports, 2013; 2013: bcr2013200156.

16. RAZEK AA, HUANG BY. Soft Tissues Tumors of the Head and Neck: Imaging-based Review of the WHO Classification. Radio Graphics, 2011; 31: 1923-1954.

17. SHINAGARE AB, et al. A to Z for Desmoid Tumors. American Journal of Roentgenology, 2011; $197: 1008-1014$.

18. TEIXEIRA LE, et al. Extra-abdominal Desmoid Tumor: Local Recurrence and Treatment Options. Acta Ortopédica Brasileira, 2016; 24: 147-150.

19. XIAOSHUANG N, et al. Radiotherapy in the treatment of primary or recurrent unresectable desmoid tumors of the neck. Journal Cancer Investigation, 2019; 37: 387-392.

20. ZUMARRAGA JP, et al. Extra-abdominal desmoid tumor: analysis of 23 consecutive cases in a single institution. Acta Ortopédica Brasileira, 2018; 26: 244-247. 